\title{
Туристический и научно-образовательный потенциал щелочно-ультраосновного массива Африканда в качестве геопарка
}

\author{
Хубер М. ${ }^{1}$, Мокрушин А.В. ${ }^{2}$, Жигунова Г.В. ${ }^{3}$, Лата Л. ${ }^{1}$, Скупински С. ${ }^{1}$, Яковлева О. ${ }^{1}$ \\ ${ }^{1}$ Университет Марии Кюри-Склодовской, Люблин, Польша, mhuber@poczta.umcs.lublin.pl \\ ${ }^{2}$ Геологический институт КНЦ РАН, Anатить \\ ${ }^{3}$ Мурманский арктический государственный университет, Мурманск
}

Аннотация. Рассмотрены предпосылки организации геопарка в Мурманской области на территории щелочно-ультраосновного массива Африканда с учетом доступности и туристической привлекательности геологического объекта. Создание геопарка будет содействовать начальному и среднему экологическому, историческому и минералогическому образованию, организации летних школ и просветительских маршрутов.

Ключевые слова: геотуризм, геопарк, комплекс Африканда, Фенноскандинавский щит.

\section{Touristic and educational potential of the Afrikanda alkaline-ultrabasic massif as a geopark}

\author{
Huber M. ${ }^{1}$, Mokrushin A.V. ${ }^{2}$, Zhigunova G. ${ }^{3}$, Lata L. ${ }^{1}$, Skupiński S. ${ }^{1}$, Yakovleva O. ${ }^{1}$ \\ ${ }^{1}$ Maria Curie-Skłodowska University,Lublin, Poland; mhuber@poczta.umcs.lublin.pl \\ ${ }^{2}$ Geological Institute, Kola Science Centre, Russian Academy of Sciences, Apatity, Russia \\ ${ }^{3}$ Murmansk Arctic State University, Murmansk, Russia
}

\begin{abstract}
The article provides background for establishing a geopark in the Murmansk region on the territory of the Afrikanda alkaline-ultrabasic massif, considering the availability and tourist attractiveness of the geological object. The establishment of the geopark will promote primary and secondary environmental, historical and mineralogical education, summer schools and educational routes.
\end{abstract}

Key words: geotourism, geopark, Afrikanda complex, Fennoscandian Shield.

The Afrikanda alkaline-ultramafic massif is one of the smallest intrusions in the Devonian $(\sim 380 \mathrm{Ma})$ Kola Alkaline Province that hosts more than twenty plutonic and subvolcanic bodies, including alkaline, ultramafic, carbonatite, and melilitolite suites. The massif has a $11.5 \mathrm{~km}^{2}$ circular shape at the current level of erosion (Kukharenko et al., 1965; Arzamastsev et al., 2000). The Afrikanda perovskite-magnetite deposit is confined to the central part of the massif, where coarse-grained clinopyroxenites dominate (>50\%). The ore comprises $15-35$ vol \% of Ti-rich magnetite and $10-36$ vol \% of perovskite and shows wide variations in the abundance of silicate minerals and calcite, reflecting extreme petrographic heterogeneity of this deposit (Afanasyev, 2011).

The Afrikanda massif occurs in the western part of the Kola Peninsula. It is a part of the alkalineultrabasic series of Paleozoic massifs of the Fennoscandian Shield (Kovdor, Turiy Mys, Sebl'yavr, Vuoriyarvi and other intrusions). The Kovdor intrusion and the associated magnetite ores are not accessible to tourists because of mining activities. Remaining smaller intrusions are basically either hard to reach or covered with sediments. In case of the Afrikanda massif, we have the important Murmansk - St. Petersburg railway line and a $3 \mathrm{~km}$-long road that leads from the railway station to closed quarries. However, the exposures are wellpreserved (Fig. 1). At present, the best exposure is in the main quarry with one clearly visible exploitation level and overburden rocks. In the exposed quarry walls, it's possible to observe pyroxenites, hornblendites and transition rocks, as well as ores containing magnetite and perovskite (Huber, 2017).

In the Afrikanda area, it would be possible to carry out renovation works based on existing and operating infrastructure, which can be renovated by adopting existing buildings for exhibition, conference, tourist and educational purposes. The works could be carried out at several stages. At the first stage, existing facilities should be preserved and renovated, the staff should be hired. Next, a number of educational and recreational paths could be constructed, quarries could be cleaned. Due to the small size and high touristic attractiveness of the area, it could be adjusted for sightseeing, including such extreme variants, as line-parks and motocross slopes, etc. 

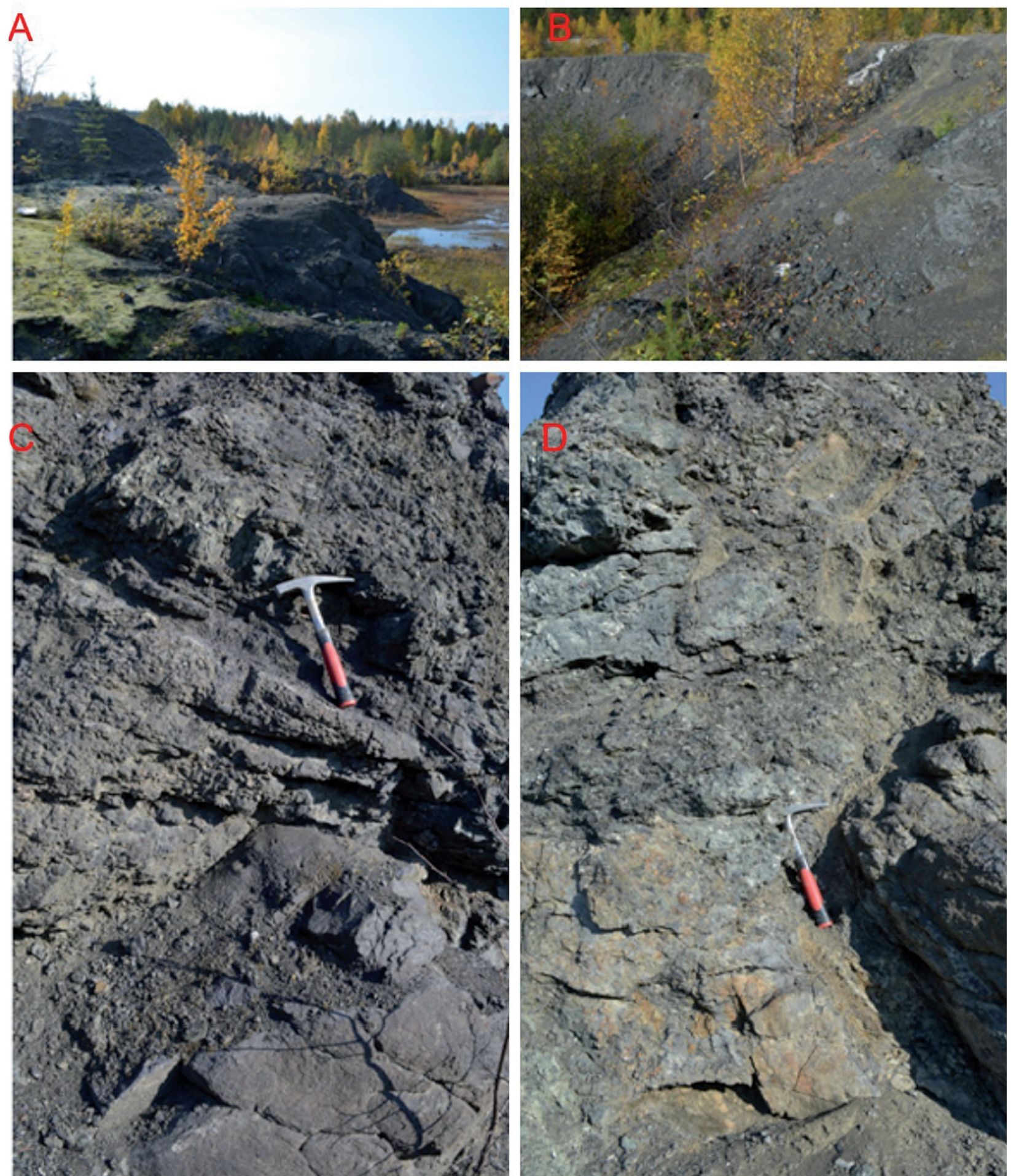

Fig. 1. General view of the quarry of the Afrikanda massif: A, B - quarry walls; C, D - transitions of clinopyroxenites (C) and perovskite ores (D).

Рис. 1. Общий вид на карьер массива Африканда: A, B - стенки карьера; C, D -клинопироксениты (C) и перовскитовые руды (D).

The Afrikanda massif could become a showcase that would initiate the tradition of geotouristic adaptation of various places on the Kola Peninsula. Similar solutions are known around the world, where didactic paths, scientific and exhibition centers are built in geologically peculiar places. They are made available to visitors, at the same time preventing their devastation and littering. Planning of educational paths, exhibition halls of a multimedia and multisensory nature may also contribute to the economic 

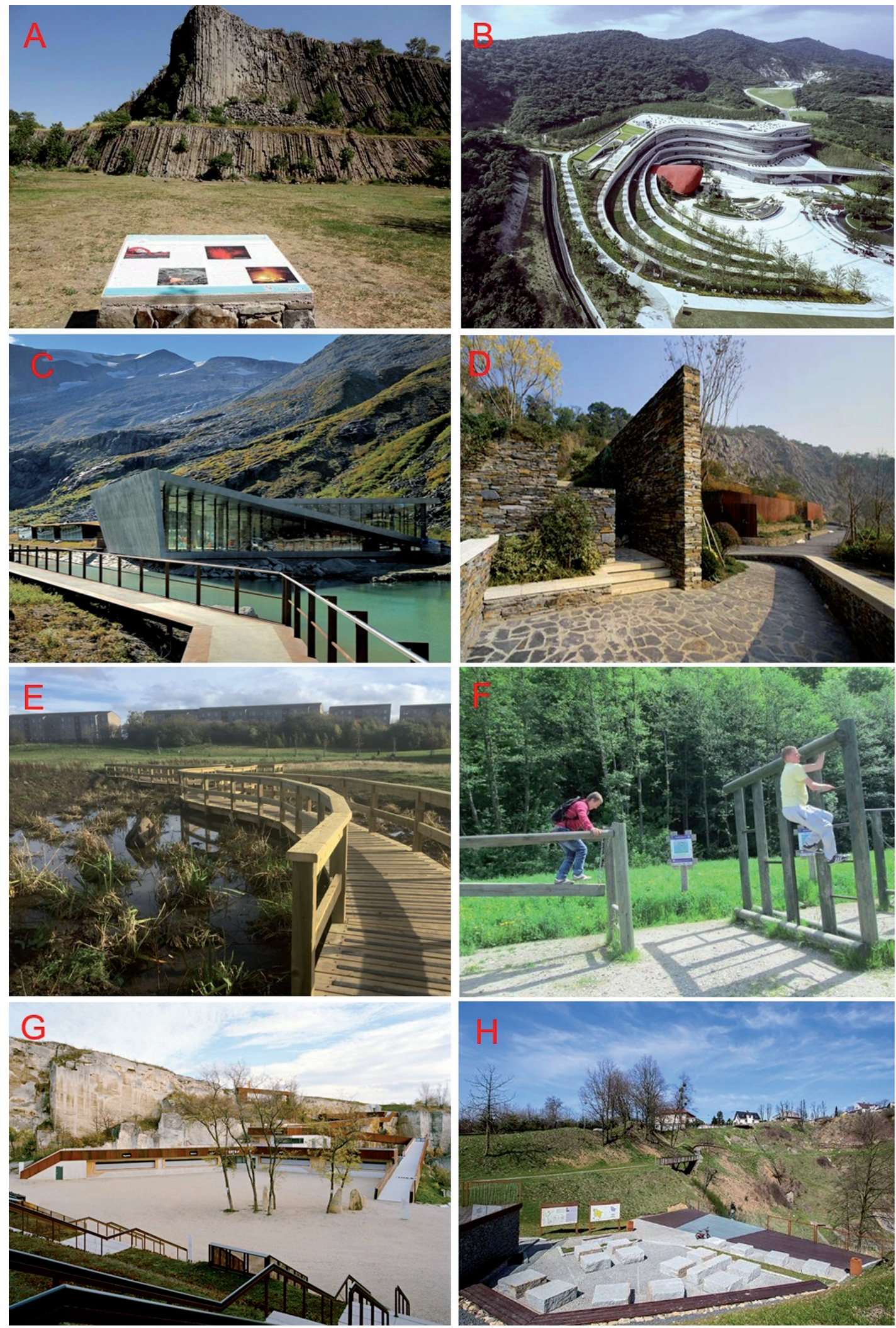

Fig. 2. Examples of revitalization of an abandoned quarry: educational board (A), geocentrum-museum (B, C), paths $(D, E)$ among wetland $(E)$, health path $(F)$, ground at the bottom of the quarry $(G, H)$ (origin of these photographs: www.google.com).

Рис. 2. Примеры реновации заброшенного карьера: информационный щит (A), геологический музей (B, C), тропинки (D, E) в заболоченной местности (E), тропа здоровья (F), сквер на дне карьера $(\mathrm{G}, \mathrm{H})($ источник этих фотографий: www.google.com). 
recovery of the region and promote the qualified tourism. At the next stage, it would be possible to develop tourist attractions in the region based on private capital. The Afrikanda geopark could be a showcase for different strategies of renovating of the Kola region. A large tourist flow and the presence of hotels in the area could ensure the permanent access of tourists by setting billboards on the roads and creating web-sites on the Internet. Finally, a network of geotourist sites should be created in the region, including a network of trails and shelters. Numerous examples from neighboring Finland and Norway indicate the great potential of these areas and their touristic attractiveness.

The construction of tourist infrastructure may be based on the known global solutions (Fig. 2), taking into account local traditions. An example of successful investments in such remote, as Lovozero, indicates the tourist interest in the discussed region. The potential of this place can be used to promote tourist values of the Murmansk region. This site is a good background for creating new places, showing the beauty of nature and allowing all interested people to get acquainted with it. The activities can be monitored on-line. Educational and demonstration paths may be constructed, taking into account cultural features, landscape and natural values. The construction of a small observation platform on the top of the Afrikanda hill allows orienting in situ and enjoying the panorama of numerous hills, the Khibiny Mountains and Imandra Lake. The view becomes more attractive, as it is enlightened by LED lamps. The energy needed for these purposes could be obtained from renewable sources (e.g. wind). Weekend tourism could be promoted by setting up camp sites. This stage does not require a lot of inputs and will help to organize tourism in this place. Furthermore, outdoor events, performances and joint events can be arranged in Afrikanda. They will draw the attention to this extraordinary place, raising awareness about the region and its environment. An important step would be to build an interactive geocentre and amusement park in the discussed area. Notably, the important advantage of this place is the lack of conflicts of interest resulting from the lack of existing plants and other entities that would be hindered by the expansion of the town.

\section{References}

1. Afanasyev BV (2011) Mineral resources of the alkaline-ultramafic massifs of the Kola Peninsula. Roza Vetrov, St. Petersburg, p 224 (in Russian).

2. Arzamastsev A, Glaznev V, Raevsky A, Arzamastseva L (2000) Mor-phology and internal structure of the Kola Alkaline intrusions, NE Fennoscandian shield: 3D density modelling and geological implications. J Asian Earth Sci 18:213-228.

3. Huber 2017; Ultrabasic-Alkaline Intrusion in Afrikanda (N Rosja) petrology -geochemistry analysis. Sciences Publisher pp. 87 (POL).

4. Kukharenko AA et al (1965) The Caledonian complex of ultrabasic and alkaline rocks and carbonatites of the Kola Peninsula and Northern Karelia. Nedra, Leningrad. 